\title{
Law and Culture in the District Court of Honolulu, 1844-1845: A Case Study of the Rise of Legal Consciousness
}

\author{
by Mari J. Matsuda*
}

\section{INTRODUCTION}

This article considers the role of Western law in the transformation of Hawaiian culture. The transformation is revealed through the newly-translated Minute Books that recorded the day-to-day business of the lowest level courts of the middle period of the Hawaiian monarchy. The Minute Books for the District of Honolulu, 1844-1845, show that native Hawaiian commoners actively embraced the Western system of law and courts. This article searches through the Minute Books for the answer to these questions: Why did the Hawaiians adopt with enthusiasm the idea of legal redress for grievances? To what extent did Western legal ideas enter the consciousness of ordinary Hawaiians? How did Western legal consciousness ${ }^{1}$ con-

* Assistant Professor of Law, University of Hawaii, The William S. Richardson School of Law.

1. Legal historians of the critical bent are increasingly concerned with the phenomenon of legal consciousness, that is, with the historical role of the belief systems underlying legal doctrine. See, e.g. . Gordan, Critical Legal Histories 36 Stan. L. Rev. 57, 101 (1984) ("Given what so often appears to be the indeterminacy of instrumental effects, a promising approach for such study may be to treat legal forms as ideologies and rituals whose 'effects'-effects that include people's ways of sorting out social experience, giving it meaning, grading it as natural, just, and necessary or as contrived, unjust and subject to alteration-are in the realm of consciousness.")

Critical legal theorists are criticized for failure to provide evidence that legal consciousness exists as an empirically identifiable phenomenon, and challenged to explain how, when, and why particular versions of legal consciousness come and go from a historical scene. See, e.g., Kornhouser, The Great Image of Authority 36 Stan. L. Rev. 349, 379 (1984) ("Critical legal theory *** simply asserts that the law is in fact ideological, without explaining how particular individuals come to adhere to the legal ideology.")

David Trubek asks in Where the Action Is: Critical Legal Studies and Empiricism 36 Stan. L. Rev. 575, 610 (1984):

Where do the processes of the production and the critique of consciousness occur? If legal consciousness is a code containing false messages, who are the recipients of these messages? 
tribute to the erosion of Hawaiian culture, folk-law, ${ }^{2}$ and ultimately, Hawaiian sovereignty?

The Honolulu Minute Books reveal a time of cultural change. The majority of the cases dealt with such matters as theft, property ownership disputes, and fencing-in violations. These cases exemplify the emerging urban, westernized character of Honolulu in the mid-1840s. Evidence of the persistence ${ }^{3}$ of Hawaiian cultural practices-status-achievement ${ }^{4}$ through exchange of property, aversion to bad thoughts and disharmony, and ready dissolution of bad marriages-exists in the cases, but evidence of the breakdown of cultural practices eclipses evidence of continuity.

This article suggests that the Hawaiians lost an important part of their cultural heritage as they flocked to the new courts to resolve disputes and to punish crimes. Disputes resolved in the new courts of law were not resolved at all in the sense of restoring good feelings. A judgment was awarded, a dispute ended, but the thing most important to the Hawaiians-peace within and acceptance by all-was not necessarily attained. The rise of what some call legalism ${ }^{5}$ may have been inevitable in Hawaii, but it is useful to ask, as the debate over legalism continues, whether this was good.

In addition, the institution of law necessarily carried ideological content that displaced important indigenous ideology. Most significant for the Hawaiians, in this respect, was the nineteenth century ideology of individual, absolute ownership of property. The Minute Books evidence the ideological conflict over the concept of property that occurred in Hawaii in the decades following initial Western contact.

This article will begin by discussing pre-contact native Hawaiian culture and offer a brief history of the reception of Western law in Hawaii. This history is intended to illuminate the enormity of the clash of consciousness that took place in the period addressed here. The article will next describe the typical cases presented in the Minute Books. This description is followed by an analysis of the rise of legal consciousness in Hawaii, suggesting how and why it occurred, and using the Minute Books to

This article attempts to identify a point in Hawaiian history when Western legal consciousness began to emerge and displace traditional Hawaiian consciousness, and to describe some elements of that displacement, with tentative attempts at explanation.

2. The term "folk-law" follows anthropological usage and refers to indigenous rules of social control that differ from Western law and legal institutions.

3. See infra text accompanying notes 59-63.

4. Use of the word "status" follows the usage of cultural anthropologists and carries the misleading implication of frantic competition for social standing. Some scholars suggest that "self-worth" better captures the Hawaiian purpose attached to gift-giving. I thank Lilikalā Kame'eleihiwa for this insight.

5. "Legalism" as used here refers to the use of Western legal rules, cases, and statutes, interpreted by courts, to govern human relations. Legalism encompasses the belief that such a system is capable of rising above politics in order to provide a neutral, stable, and just means of mediating disputes and governing social life. 
demonstrate the role of ordinary Hawaiian citizens in bringing about a new era of Western legalism in the islands.

\section{BACKGROUND HISTORY}

To understand the context of the court records examined in this article, it is necessary to provide a simplified ${ }^{6}$ historical background.

\section{A. Pre-Contact Hawaiian Culture ${ }^{7}$}

The native Hawaiians, descendants of the Polynesian voyagers who discovered the islands some 1,400 years before Captain Cook, had a vital culture and system of folk law. The day-to-day involvement with the spiritual world was a binding element of Hawaiian culture. The Hawaiians had explanations for all natural phenomenon. They saw the universe as an interconnected whole where everything had a place. Their religion celebrated nature and respected many gods, including personal ancestral gods for each family ${ }^{8}$ The Hawaiians knew that certain acts were prohibited and that harsh punishment, including death, would follow violation under the

6. This summary cannot do justice to the richness and uniqueness of Hawaii's history. The background history offered here omits issues of explanation and interpretation, and is not offered as a substitute for the many secondary sources available in the field of Hawaii history. This description draws from R. Kuykendall, The Hawaiian Kingdom (1965); G. Daws, Shoal of Time (1968); E. Joesting, Hawaii, An Uncommon History (1972); M. Sahlins, Islands of History (1985); L. Kame'eleihiwa, Land and the Promise of Capitalism: A Dilemma for the Hawaiian Chiefs of the 1848 Mahele (forthcoming); Valeri, Kingship and Sacrifice (1985).

7. This description is problematic because no written contemporaneous records exist describing pre-contact Hawaii. See generally Kelly, Some Problems of Early Descriptions of Hawaiian Culture, in Polynesian Culture History (G. Highland, R. Force, A. Howard, M. Kelly, and Y. Sinoto eds. 1967). The sources used in deriving this description rely on archeological findings, Hawaiian oral traditions, journals of the first Western visitors, and post-contact observation of Hawaiian culture. The writings of Hawaiians familiar with the old ways are particularly useful. See, e.g., S. Kamakau, Ruling Chiefs of Hawaii (1961); D. Malo, Hawaiian Antiquities (Moolelo Hawail) (N. Emerson trans. 1898). The Hawaiian writers closest to pre-contact culture were missionary-educated, thus this source is also subject to bias. Ethnographies by current observers of Hawaiian culture and contemporary Hawaiian informants also provide a view of Hawaiian culture as it exists today, suggesting the continuity of Hawaiian values. See, e.g., J. Linnekin, Children of the Land (1985); M. Pukui, E. W. Haertig, C. Lee, Nana I Ke Kumu vol. II (1972) (hereinafter M. Pukui). While these ethnographies are susceptible to the folly of imposing the present upon the past, it is nonetheless this writer's belief that there was and is an identifiable native Hawaiian culture, which available evidence identifies for consideration by legal historians.

8. For a description of Hawaiian religion and gods, see R. Kuykendall, supra note 6, at 7; D. Malo, supra note 7. Personal ancestral gods, the aumakua, are discussed in M. Pukui, supra note 7, at 123. See also M. Sahlins, supra note 6 . 
first folk-law of Hawaii, the religious kapu. ${ }^{9}$ While the kapu system had a religious basis, it also met practical needs. Fishing season kapu, for example, conserved a basic protein source. ${ }^{10}$ Thus, the kapu represented a system of what contemporary jurists might call public law. The kapu system was a strong source of social control in ancient Hawaii, working in concert with the spiritual beliefs of Hawaiians.

Prayers to the gods accompanied such common activities as housebuilding, tree-cutting, circumcision, war-making, and celebration. ${ }^{11}$ Illness and death were often attributed to the curses of skilled priests invoking the powers of the gods. Hawaiians would seek the service of such priests to ward off the curses of others, or to wish death upon enemies. ${ }^{12}$

The Hawaiians valued harmony, and feared the evil thoughts of others. ${ }^{13}$ Several descriptive terms in the Hawaiian language disparage various forms of human unpleasantness. Being nosey, pesty, complaining, avaricious, vain, or acquisitive of material wealth were considered the worst of traits. ${ }^{14}$

Disputes among Hawaiians were resoloed through the cultural practice of ho'oponopono. ${ }^{15}$ In the ho'oponopono ceremony, disputants, their relatives, and religious leaders, gathered together to pray for divine guidance and to air grievances. ${ }^{16}$ Each person in turn would pour forth their version of the facts, their anger, their grief, and their claim for a just result. Bitter charges of dishonesty, exaggeration, and selfishness would mount, with the accused forced to listen until their turn came to respond. The opinions of elders or religious leaders directed the process, which continued, at times, for days. The process ended when the emotionally spent parties realized their fundamental connection to each other and repented their individual acts of selfishness and deviation from communal norms. Embraces, tears, and exaggerated acts of generosity toward the former opponents ended the

9. E. Handy, Government and Society, lecture transcribed in K. Emory, E. Bryan, P. Buck, J. Wise, Ancient Hawaiian Civilization 35 (1965). Eating kapu are described in D. Malo, supra note 7, at 27.

10. Fishing kapu are described in R. Kuykendall, supra note 6.

11. D. Malo, supra note 7, at 118-134, 93-94.

12. Id. at 112 .

13. M. Pukui, supra note 7 , at 225-230.

14. D. Malo, supra note 7, at 72-76; M. Pukui, supra note 7, at 225.

15. See M. Pukui, supra note 7, at 230. "Ho' oponopono" is translated "to correct." "Pono pono" is "neat, in order, arranged." M. Pukui, S. Elbert, and E. Mookini, The Pocket Hawaiian Dictionary (1978).

16. E. Shook, Ho'oponopono I (1985). 
ceremony, as each party expressed shame and remorse for their nowabandoned contentiousness. ${ }^{17}$ Ultimate forgiveness was the goal. ${ }^{18}$

The inevitability of this result may seem odd unless one understands the Hawaiian social context. In a community where people lived and worked closely together, failure to resolve a dispute in a way that satisfied all parties led to more disputes that the community, which required the productive labor of all, could not tolerate. A dispute resolution process from which some would walk away bitterly disappointed was unthinkable in this context. Hawaiians lived in villages tied by kinship. ${ }^{19}$ Hawaiian survival was tied to the most demanding and complex agricultural system in all of Polynesia. ${ }^{20}$ Hawaiian-made irrigation systems, fish cultivation systems, and trade networks required the cooperation, obedience, and collective effort of thousands of individuals who saw themselves, as revealed in their geneologies, as ultimately related to each other, to the land and its gifts, to the chiefs, and to the gods. ${ }^{21}$

In this kinship community, there was no cash economy nor was there any bartering. It was considered shameful to drive a hard bargain,

17. For an abbreviated example of a ho'oponopono session, see id. at 13.

18. The forgiveness granted was total: "Mai ka piko oke po"o a ka poli oka wawae, a ma na kihi 'eha o ke kino" ("From the top of the head to the soles of the feet and [between] all four corners of the body") M. Pukui, supra note 7, at 247.

19. E. Beechert, Working in Hawaii A Labor History I (1985).

20. See B. Krauss, Ethnobotany of the Hawaiians (forthcoming). Professor Krauss has stated in an interview: "No Polynesians had a more excellent method of irrigation than the Hawaiian lo'i system of taro." D. Thomas, View's From Another World XXI Honolulu 104, 166 (1986). Edward Beechert describes the process of building taro terraces:

Building the terraces, large or small, was a heavy task. Large groups of men were required for a project that could take months or even years to complete, depending on the size and shape of the land. From one hundred to a thousand workers were assembled to perform this work. First water was allowed to flow over the land selected. Again, the men would feast beforehand; then they lined up at the lower edge of the field where they began to heap up the soil with their hands. This process continued until the terrace was level. After the sides had been packed by tramping, surgarcane tops, coconut fronds, and grass was tamped into the sides, which were then covered with flat stones, fine soil, and grass to prevent drying out. When the terrace was completed, the next step was to make a floor. At this point the women and children joined in. Water was flooded over the floor and the people packed the mud with their feet. This task frequently took on the air of a festival. Finally, the men planted the taro and lined the banks with sugarcane and banana plants." E. Beechert, supra note 19 , at 3 .

21. For discussions of the communal, agrarian nature of Hawaiian society see $R$. Kuykendall \& A. G. Day, Hawaii. A History (1961); E. Beechert, supra note 19; R. Kuykendall, supra note 6; Malo, supra note 7. Lilikalā Kame'eleihiwa states: Geneologies are perceived by Hawaiians as that unbroken chain which links man in the present to those primeval life forces, that mana, which first emerged with the beginning of the world. L. Kame'eleihiwa, supra note 6 , at 24 . Kame'eleihiwa also describes the centrality of the concepts of pono (the universe in perfect balance) and malama'aina (care for the land) in Hawaiian thought. Id. at 31-34. 
or to fail to share with others in need. ${ }^{22}$ The traditional Hawaiian open living area provided no protection against theft. ${ }^{23}$ While rare thieves were known and scorned, theft was not a problem in the typical Hawaiian community where everyone was related and giving was an important social practice. ${ }^{24}$ Cultural restraints against theft in such an interdependent community were strong.

The pre-contact Hawaiian social organization is described as more hierarchical than that of other Pacific island groups. ${ }^{25}$ Distinct classes of great and lesser chiefs, retainers, priests, and commoners were recognized. Chiefs could impose kapu, extract taxes, dispense favors and impose punishment. The chiefs, or ali' $i$, formed an elite with authority over the vast majority of commoners, or maka'ainana. ${ }^{26}$ The highest chiefs were surrounded by kapu so strict that they rarely ventured out in daylight. To do so would greatly inconvenience the citizens. The people fell prostrated upon the ground in the presence of a high chief, or even before the food prepared for him as it was carried by. ${ }^{27}$

Into the Hawaiian's land of natural abundance ${ }^{28}$ and strict social hierarchy came the explorers, traders, whalers, and missionaries who spread across the Pacific. Between the arrival of Captain Cook in 1778 and the middle monarchy period that is the subject of this paper, several significant Westernizing influences invaded Hawaii's shores.

\section{B. Western Contact and Western Law}

The arrival of the haole in 1778 tested the existing modes of norm enforcement. Haole ${ }^{29}$ broke kapu openly, without apparent consequence. They introduced Western goods, which they traded for food, water, and the attentions of Hawaiian women.

22. For a contemporary ethnography of a Hawaiian community describing the shame associated with covetous bargaining, see generally J. Linnekin, Children of the Land (1985).

23. Open homes are described in D. Malo, supra note 7.

24. M. Pukui, supra note 7 , at 166-177.

25. See, e.g., K.R. Howe, Where the Waves Fall, A New South Sea Islands History From First Settlement to Colonial Rule 40 (1984).

26. The word "ali' $i$ " is sometimes translated as "king" or "monarch," but scholars of Hawaiian language suggest that Western concepts of royalty are not accurately applied to the ali' $i$. The ali' $i$ were representative of the best of the maka'ainana, thus the relationship between the classes was part vertical, part horizontal. See L. Kimura, Language Section of Native Hawaiians Study Commission Report, 182-183 (1983).

27. D. Malo, supra note 7 , at $54,57$.

28. Times of hardship, war, and famine did occur during the long history of Hawaiian presence in the islands. At the time of first Western contact, however, Hawaiians were living in a state of relative plenty that much impressed the first outside observers.

29. "Haole" means outsider, and is used generally to refer to Caucasians. 
Hawaii's strategic location, whaling, and the sandalwood trade all in turn brought many foreign ships in the fifty years following first contact. ${ }^{30}$ Newcomers, who began arriving with regularity in 1786 , introduced disease, liquor, gambling, prostitution, carousing, and other artifacts of western civilization. It was said that "there is no God and no law west of Cape Horn." 31 The need to control foreigners introduced Hawaii's ali' $i$, by then an established Western-style monarchy, to the concept of sovereignty. They learned that they could charge docking fees to foreign ships, and that attempts to punish foreigners for crimes might lead to military or diplomatic retaliation by other nations. ${ }^{32}$ The ali' $i$ also developed a taste for Western wealth and status symbols, which led to increased demands upon commoners to produce goods for trade. ${ }^{33}$

A major impetus toward the introduction of Western law came from the breakdown of the old religious kapu and the arrival of the missionaries in 1820. These descendants of the puritans came from Massachusetts, just when the old religious order was breaking down. The missionaries fell easily into the traditional role of Kahuna nui, religious advisor to the ali' $i$, and the elite Hawaiians proved adept at altering their consciousness in response to the demands of outsiders. ${ }^{34}$ The first written criminal law, which appeared in 1827 , generally followed the ten commandments. ${ }^{35}$

30. Foreign ships began arriving regularly in 1786. R. Kuykendall, supra note at 6 , at 20 .

31. This motto of western lawlessness is noted in the L. Thurston, Writings of Lorrin Thurston 7 (1936).

32. See Frear, Hawaiian Statute Law, 13th Report of the Hawaiian Historical Society (1906); R. Kuykendall, supra note 6, at 120-121.

33. C. Daws, supra note 6, at 45; K.R. Howe, supra note 25, at 165.

34. Kame'eleihiwa discusses the Kahuna role of the missionaries who the ali' $i$ perceived would help control foreigners in the wake of the collapse of the kapu system. L. Kame'eleihiwa, supra note 6.

35. The 1827 law stated:

\section{WORDS ABOUT THE LAW}

We proclaim these words, hearken those of that land and those of this land, those of this land shall also obey, and those of that land also shall obey, those that hear these words, shall obey; but if it is not obeyed he shall be guilty.

I

We forbid murder; those of that land must not commit murder here, those of this land must not commit murder; the one who commits murder shall die, by being hung.

II

This is the second; we forbid theft; the one who steals shall be put in irons.

III

This is the third; we forbid illicit intercourse between a male and female; and the illicit intercourse between a female and male, the one who has illicit intercourse, shall be imprisoned in irons. 
The missionaries arrived at the same time that pressure from foreign contact was moving the Hawaiian nation into the global community. Hawaii's monarchy felt the need for a fixed legal system and they sought advice from missionary advisors ${ }^{36}$ in efforts to buffer the advances of foreigners and foreign governments. To Native Hawaiian petitioners asking the King to keep non-Hawaiians out of public office, the King responded:

I have appointed foreign officials, not out of contempt for the ancient wisdom of the land, but because my native helpers do not understand the laws of the great countries who are working with us. That is why I have dismissed them. ${ }^{37}$

During the monarchy period Hawaii faced threats to its sovereignty from England, France, Spain, Russia, and the United States. ${ }^{38}$ Hawaii did not have the military power to defend itself from aggressors, and it had to use instead its natural claims to sovereignty, and the shaky but mutually advantageous agreement among Western nations to respect Hawaiian sovereignty so as not to upset the global balance of power. In this precarious position, Hawaii developed as a nation. The monarchy instituted a constitution, and began sharing some power with a partially elected legislature.

This is the fourth; we forbid the selling of rum here; the one who sells rum, shall be put in irons.

V

This is the fifth; we forbid prostitution; the one who is a prostitute, shall be fined in money.

VI

This is the sixth; we forbid gambling; the one who gambles shall be imprisoned in irons.

(Translated from Hawaiian)

36. Reverend Bingham is quoted as saying: "It is not for the mission to give laws to the natives, nor to interfere with the authority of the chiefs, nor to engage in commercial speculations, nor to be known otherwise than as propagators of the Gospel." W. Westervelt, Hawaiian Printed Laws Before the Constitution. Sixteenth Annual Report of the Hawaiian Historical Society (1908). However, missionaries found involvement with secular affairs unavoidable in order to counteract influences of other outsiders. Non-missionary foreigners lobbied against adoption of the Ten Commandments as Hawaii's criminal law, and they succeeded in limiting the number of proscribed offenses. R. Kuykendall, supra note 6, at 124.

37. Kamehameha III, letter of July 1845, quoted in D. McGregor-Alegado, "Voices of Today Echo Voices of the Past," in Malama, Hawaiian Land and Water (D. Hall ed. 1985).

38. G. Daws, supra note 6, at 51 (Russia in 1815), and at 103 (France in 1839); R. Kuykendall and A. G. Day, supra note 21, at 33; R. Kuykendall, supra note 7, at 212-213 (France and England), and at 21 (Spain in 1791). 
Courts were established to handle disputes of natives and foreigners, and comprehensive statutes modeled after American examples were adopted. ${ }^{39}$ By 1842 , several statutes ${ }^{40}$ proscribed specific offenses, identifying various degrees and schedules of penalties. Penalties were specified for, inter alia, swift riding of horses, letting loose of mischievous beasts, failing to pay debts, and failing to pay taxes. ${ }^{41}$ The doctrinal body of nineteenth century Western law had made its official arrival in the islands.

\section{THE DISTRICT COURT MINUTE BOOKS}

The formal introduction of Western law and the proliferation of statutes raises questions about how the law was applied in fact. The primary sources of legal history of the monarchy period are now becoming available to scholars making this inquiry. In 1980, Professor Esther Mookini began the enormous task of translating the handwritten records of the lowest level courts of the monarchy from Hawaiian into English. ${ }^{42}$ These translations form the primary source for this article.

The District Courts were not officially courts of record, although careful records of their proceedings were kept. The proceedings were conducted in Hawaiian by non-lawyer Hawaiian judges. The parties were virtually all Hawaiian commoners, untrained in the law and not represented by counsel. The proceedings of the District Courts thus provide insight into the developing legal consciousness of ordinary Hawaiians in the initial period of reception of Western law.

The insights presented in this article reflect, first, impressions gleaned from reading the cases, and second, the results of quantification of certain telling variables listed in the accompanying tables.

\section{A. Some General Impressions}

The first entry in the Minute Books, ${ }^{43}$ dated January 1, 1944, is prefaced:

39. See Hawaii Constitution and Laws of 1840 .

40. See H. Ball \& Moriyama, Laws of 1842: Penalties (unpublished compilation).

41. Id.

42. This paper would not have been possible without the scholarly work of Professor Mookini and her students. The author is deeply indebted to them for translating the primary source used in this article.

43. The Minute Book entries are not paginated and are therefore referenced by date in this article. 
1. This is a book for everything done including all the trials by the judges at the Fort of Honolulu.

2. Recorded in this book will be all the trials, significant and insignificant, the decisions, and if there were or were no penalties.

The preservation of low-level records purporting to record "everything significant and insignificant" is the stuff of a legal historian's dream. The Minute Books are true to their simply-worded preface. What is immediately striking about the Minute Books is the high level of activity they reveal. The books are reminiscent of the records of some American colonial courts in that they provide a small-town, everybody's-business-is-everybody's-business atmosphere. ${ }^{44}$ Small offenses, petty grievances, and interpersonal spats were frequently before the courts. ${ }^{45}$ Rather than the wary use of a new institution, the picture that emerges is one of Native Hawaiians actively embracing and using the law and the courts.

Other immediate impressions include those typically seen in newlyemerging, non-lawyer courts: lack of clear distinction between civil and criminal cases, ${ }^{46}$ role of confusion of judges and litigants, ${ }^{47}$ blending of questions of law and questions of fact, ${ }^{48}$ compromise decisions, ${ }^{49}$ and selective enforcement. ${ }^{50}$ Statutes, cases, and specific legal authority were never cited as reasons for results.

Also notable is the general level of fairness or rough justice in the decisions. In criminal cases, a 26 percent non-conviction rate indicates that

44. See, e.g., The Pynchon Court Record (J. Smith ed. 1961).

45. See, e.g., Hiahia and Kamahulihia, June 28, 1844 (Hiahia charged that Kamahulihia threw Hiahia's cotton dress into the sea while Hiahia was swimming. The judges dismissed the case).

46. In Kenoi and Kamanuwai, January 8, 1844, for example, Kenoi admits stealing a pig. The victim/pig owner was asked "what was the price." The judges awarded \$12.00 to the pig owner and also charged Kenoi $\$ 8.00$ "to the government."

47. In Kapule and Naihe, January 1, 1844, for example, Kapule is represented by "John Ii, his attorney, while the judges were appointed to Naihe's side." The governor and temporary judges adjudicated the case.

48. Judges decided questions of both law and fact in the district courts. Legal authorities, statutes, and precedents were almost never cited, with rare references to "the law." Most cases turned on the facts.

49. See Kaoluio and Kalua, discussed infra. In Halai and Co., Nahinu and Kahula, January 4,1844 , a typical fencing case, the judges charged Nahinu 50 cents because his pig ate Halai's taro, and charged Halai 50 cents for damage to the pig. In Poo and Pookole, January 13,1844, a dispute over the price of poi, the judges concluded "Poo, because your suit is confusing, here is what is right. The hapawalu ( $1 / 8$ of one dollar) is yours, the poi is Pookole's," essentially returning the parties to their pre-transaction position.

50. Certain laws are enforced regularly; others not at all. 
TABLE I

CONVICTIONS/NONCONVICTIONS

\begin{tabular}{lcc}
\hline & Number & Percent \\
\hline Conviction & 230 & 51 \\
Nonconviction & 117 & 26 \\
Result Unreported & 104 & 23 \\
& $451-$ Total & $100 \%$ \\
Morals Offenses & & \\
Conviction & 87 & 55 \\
Nonconviction & 45 & 29 \\
Result Unreported & 24 & 16 \\
\cline { 2 - 3 } & $156-$ Total & $100 \%$ \\
Public Order Offenses & & 49 \\
Conviction & 143 & 24 \\
Nonconviction & 72 & $100 \%$ \\
Result Unreported & 80 & 27 \\
\cline { 2 - 3 } & $295-$ Total & \\
\hline
\end{tabular}

the judges were at some level respecting the rights of defendants. (See Table I). Of the convictions, many defendants had confessed, thus adding a measure of assurance of guilt. Defendants claiming innocence were much less often convicted. (See Table II).

Most convictions resulted in fines or restitution. (See Table VII). Other harsh punishments, such as imprisonment, chaining, or flogging, were rarely imposed-in part, no doubt, because of the lack of facilities.

Kaoluio and $\mathrm{Kalua}^{51}$ is an example of the approximate justice dispensed in the Honolulu District Court. Kalua charged that Kaoluio "punched me on my temple, cheeks and chin."

Kaoluio, in defense, stated he merely "rapped him on the forehead" and complained that Kalua was indebted to him.

The judges rendered a compromise decision, cancelling Kalua's debt and dismissing the assault charge against Kaoluio. Kaoluio, who essentially had confessed to battery, was not punished as a criminal, but he did have to forego collection of the debt.

51. January $2,1844$. 


\title{
TABLE II
}

CONFESSIONS

(Theft and Adultery)

\author{
Theft \\ Confessions resulting in convictions $\quad 30$ \\ Confessions resulting in non-convictions 0 \\ Non-confessions resulting in convictions 28 \\ Non-confessions resulting in non-convictions 13 \\ Adultery \\ Confessions resulting in convictions $\quad 40$ \\ Confessions resulting in non-convictions 6 \\ Non-confessions resulting in convictions $\quad 8$ \\ Non-confessions resulting in non-convictions $\quad 18$
}

\section{B. Crimes Prosecuted in the District Court of Honolulu, 1855}

The missionaries succeeded in part in punishment of morals offenses. ${ }^{52}$ Table III shows the religious/morals offenses prosecuted in the district court. Adultery leads the list, constituting more than half of the offenses referred to here as non-economic. ${ }^{53}$ Economic or public order crimes, listed in Table IV, are those that would probably have been criminalized even without the religious influence of the missionaries. Of these, theft is predominant, with 98 cases. $^{54}$

Public order/economic offenses eclipse morals prosecutions two to one, revealing that the need to maintain a stable environment for economic growth was perhaps more socially important than the need to save souls. This pattern of economic offenses overtaking purely morals offenses has

52. The distinction between morals offenses and economic/public order offenses is problematic. Morals offenses do affect public order and economic crimes, such as theft, do have a moral component. Nonetheless, the prominence of theft over, for example, adultery, does represent a prioritization more typical of a society concerned with economic development.

53. Some historians suggest that the frequency of adultery prosecutions stems from the fact that constables were paid per arrest, and adultery was an easy crime to catch people in the act of. There were no kapu against adultery or illegitimate births in native Hawaiian culture. Sexuality was accepted as natural, and there were no associations of guilt or shame with sex. Promiscuity was disapproved of, but it was not punishable as a public wrong. Hawaiians worshipped their ancestors and kept careful geneologies. A woman who was "haka kau aka manu"-who slept with many partners--could not be certain of her child's geneology. Thus the disapproval focused not upon sexual conduct, but on the need for strong inter-generational family ties. M. Pukui, supra note 7, at 93.

54. Id. at $93-94$. 
TABLE III

MORALS OFFENSES

\begin{tabular}{lcc}
\hline \multicolumn{1}{c}{ Crime } & Number & Percent \\
\hline $\begin{array}{l}\text { 1. Adultery } \\
\text { 2. Husband-Wife Domestic }\end{array}$ & 83 & 54 \\
$\quad$ Misbehavior (“being afraid,” & & \\
$\quad$ abandonment) & 24 & 16 \\
3. Prostitution/Pimping & 20 & 13 \\
4. Sabbath Violations & 17 & 11 \\
5. Gambling & 7 & 5 \\
6. Impersonating A God & 1 & 1 \\
& $152-$ Total & $100 \%$ \\
\hline
\end{tabular}

been noted elsewhere as part of the secularization process of a growing community. ${ }^{55}$

The crime of theft is of particular interest because theft indicates a breakdown of social control and reveals attitudes toward property. In ancient Hawaii there was little excuse for one to take from another when an honest day's work would provide one with the necessities of life. Thievery in the sense of taking the work product of another without claim of communal or exchange right was rare. Since most property was used in common, there was little cause for theft in the Western sense.

The introduction of Western living had three basic effects that may have led to the increase of theft. ${ }^{56}$ First, Hawaiians left their rural homes and flocked to the harbor towns of Lahaina and Honolulu, drawn by the promises of wealth and adventure that the traders brought. As Hawaiians left the land, they also left their constant source of food and shelter, and entered the world of cash economy. In the emerging urban areas, the necessities of life could not be obtained directly by the works of the hands or sweat of the brow.

55. See, e.g., Flaherty, "Law and Enforcement of Morals in Early America" and Nelson, "Emerging Notions of Modern Criminal Law in the Revolutionary Era: A Historical Perspective," both in American Law and the Constitutional Order, Historical Perspectives (L. Friedman and L. Scheiber eds. 1978).

56. An increase in prosecution is treated here as an indicator of an increase in incidence of theft. Conclusive evidence of real crime rates is never available to historians or criminologists, but the numerous prosecutions of theft in 1844-1845 does seem to indicate a change from the conditions of prior times, given the available sources. See, e.g., (supra note 22). 
TABLE IV

List of Crimes

1844-1845

PUBLIC ORDER OFFENSES

\begin{tabular}{|c|c|c|}
\hline Crime & Number & Percent \\
\hline 1. Theft & 98 & 47 \\
\hline $\begin{array}{l}\text { 2. Insults/Swearing/Black Magic/ } \\
\text { False Accusations/Trickery }\end{array}$ & 42 & 20 \\
\hline 3. Assault & 23 & 11 \\
\hline $\begin{array}{l}\text { 4. Rioting/Brawls/Fighting/ } \\
\text { Disturbing the Peace }\end{array}$ & 16 & 8 \\
\hline $\begin{array}{l}\text { 5. Killing Animals/Injuring Animals } \\
\text { Tying Animals on Street }\end{array}$ & 11 & 5.2 \\
\hline $\begin{array}{l}\text { 6. Riding Furiously/Secretly } \\
\text { Riding A Horse }\end{array}$ & 7 & 3 \\
\hline 7. Drunkeness/Selling-Making Liquor & 6 & 3 \\
\hline 8. Rape & 3 & 1 \\
\hline 9. Breaking and Entering & 2 & 1 \\
\hline 10. Failure of Duty & 1 & .4 \\
\hline \multirow[t]{2}{*}{ 11. Counterfeit Money/Bad Money } & 1 & .4 \\
\hline & 210 - Total & $100 \%$ \\
\hline
\end{tabular}

Second, urban Hawaiians lost the social and cultural restraints against theft-shame, ostracism and moulding by elders-that were effective in the communal villages. ${ }^{57}$

Finally, Westerners introduced a whole new range of coveted goods and the trap of rising expectations. The District Court Minute Books reveal the effects of introduced goods. The majority of thefts ${ }^{58}$ were of Western, introduced goods and of cash. (See Table V). Introduced domesticated animals, money, cloth or clothing, tools, and furniture lead the list. With

57. The serious task of training children in proper behavior is discussed in M. Pukui, supra note 7 , at 54, 260-264. Hawaiians also physically shaped children by massage and manual pressure to achieve healthy and attractive physiques. Id. at 32-33.

58. Because the judges tended to concentrate on facts rather than law, the cases show no clear demarcation between criminal theft and civil conversion actions. For purposes of this article, any case in which a party claimed the wrongful taking of property is considered theft. 


\section{TABLE V}

THEFT PROSECUTION AND OWNERSHIP DISPUTES: WESTERN GOODS

\begin{tabular}{ll}
\multicolumn{1}{c}{ Goods } & Number \\
\hline 1. Western Introduced & \\
\multicolumn{1}{c}{ Domesticated Animals* } & 19 \\
2. Money & 19 \\
3. Cloth/Clothing/Clothes & 19 \\
4. Handkerchiefs & 5 \\
5. Tools & 5 \\
6. Furniture & 4 \\
7. Shoes & 3 \\
8. Tobacco/Cigars & 2 \\
9. Iron (tool to iron clothes) & 2 \\
10. Lumber & 2 \\
11. Nails & 2 \\
12. Chest & 2 \\
13. Saucepan & 2 \\
14. Jewelry & 2 \\
15. Soap & 1 \\
16. Bottles & 1 \\
17. Stockings & 1 \\
18. Saddle & 1 \\
19. Horsewhip & 1 \\
20. Liquor & 1 \\
21. Gun & 1 \\
22. Mirror & 1 \\
23. Paint & 1 \\
24. Mosquito Net & 1 \\
25. Bedding & 1 \\
26. Razors & 1 \\
27. Wool & 1 \\
28. Ribbon & 1 \\
29. Shoemaking Machine & 1 \\
30. Comb & 1 \\
& \\
\hline & \\
\hline
\end{tabular}

\footnotetext{
* 9 Horse Cases

6 Goat Cases

2 Cattle Cases

1 Duck Case

1 Turkey Case
} 
TABLE VI

THEFT PROSECUTION AND OWNERSHIP DISPUTES: TRADITIONAL GOODS

\begin{tabular}{ll}
\multicolumn{1}{c}{ Goods } & Number \\
\hline 1. Pre-contact Domesticated & \\
Animals* & 13 \\
2. Canoe & 4 \\
3. Thatch & 3 \\
4. Feathers & 2 \\
5. Sweet Potatoes & 2 \\
6. Birds & 2 \\
7. Fish & 2 \\
8. Poi & 2 \\
9. Leis & 2 \\
10. Taro & 2 \\
11. Gourds & 1 \\
12. Trees & 1 \\
13. Tapa Cloth & 1 \\
14. Pork & 1 \\
15. Pandamus Leaves & 1 \\
16. Digging Stick & 1 \\
\hline
\end{tabular}

\footnotetext{
* 10 pig cases

2 chicken cases

1 dog case
}

Note that it is unclear from the records whether these animals were native-type or introducedtype. These cases may belong in the "Western Goods" category, particularly because commoners rarely ate pork in pre-contact Hawaii.

exceptions, such as the four canoe thefts and one theft of house-building thatch, native goods were rarely the subject of theft prosecutions. (See Table VI). While many causes could exist for this disparity, it does seem that the things that Hawaiians wanted and felt constrained to obtain by theft were Western goods.

\section{Persistence of Hawaiian Culture}

The persistence of Hawaiian ideas and culture is also evident in the Minute Books, revealing the strength of Hawaiian culture in the face of a Westernized legal system. Hawaiians used the courts as a forum to air disputes that were particularly Hawaiian. Hawaiians placed value on peace in the community and particularly feared the power of enemies to wish evil upon them. Concerns over failure to make peace are evident in the cases 
involving interpersonal disputes. Several complainants brought to court the offenses of slander and swearing, alleging that the defendant had used offensive Hawaiian words or had spoken evil of them. ${ }^{59}$ Others complained of ana' ana or "black magic" practiced against them. ${ }^{60}$ The court tended to reject these complaints, imposing no fines. ${ }^{61}$

Other cultural practices, such as the abandoning of unhappy marriages, found their way into the courtroom. Many unhappy husbands and wives simply walked away or refused to engage in marital relations. ${ }^{62}$ In pre-contact Hawaii, there was no concept of being forever bound to a bad union. The missionary-introduced concept of Christian marriage led to prosecutions for desertion and "being afraid." 63

\section{Hawaiian Concepts of Property}

Hawaiians stubbornly resisted but gradually acquired the Western legal concept of property. Confusion over ownership and use is evident in the cases ${ }^{64}$ of theft or contract that follow this general pattern:

59. See, e.g., Luika and Mele, June 14, 1844 (Mele was fined $\$ 100$ for calling Luika "thief, the pimp, women who eats excreta"); Kaleo and Keakahewa, June 29, 1844 (Keakahewa was fined $\$ 3.00$ for calling Kaleo "a vagina mound ... venereal disease, destitute person . . . a stinking disease, a diseased shell"); Kaia and Pohiki, August 7, 1844 (Pùhiki fined $\$ 1.00$ for "you are despised, I will pluck you out of my eyes"); Kanoa and Poopoo, August 4, 1844 (Poopoo fined $\$ 3.00$ for calling Kanoa "a liar and a fool [with] a slippery mouth"); Nailiili and Kapihi, July 15, 1844 (Kapihi fined $\$ 1.00$ for calling Nailiili "stingy, a man who lies"); Lilikalani and Kaiaino, May 17, 1844 (no fine for saying Lilikalani was "stuck to my money," "like a dog"); Kamaka and Paaoao, June 5, 1844 (no fine for calling Paaoao a "wandering bird's beak").

60. In Kaae and Mokuhia, February 1, 1844, Mokuhia denied saying words of black magic. Result: "No fine is imposed because of the confusion."

61. Id. See also Hale and Akaulaohawaii, May 28, 1844.

62. See, e.g., Paaoao, June 19, 1844 (judges ordered Paaoao to return to her first husband when she admits she is not legally married to her present mate).

63. For example, Keino and Nahoa, January 2, 1844, reads:

Judge: Nahoa, are you afraid of your husband?

Nahoa: No.

Judge: Keino, your wife says she is not afraid.

Keino: She is afraid, we were just married.

Judge: You two, return to the place where your wife is living at and if she afraid, report to the judge of that place because your wife said that the two of you will return there.

64. See, e.g., Papohaku and Kamakahonu, June 5, 1844 ("the canoe he gave my husband. Therefore I believe the canoe is mine." Response: "In my mind there is no heir to the canoe, therefore I sent my son's servant to get the canoe"); Nahuina and Kawai, July 15, 1844 ("Because Kawai brought me this valuable and precious horse I was embarrassed because I was so poor. I did not have any money so I [gave] him my pigs." Later: "I charge Kawai of keeping the horse which he has given me and my wife"); Koloa and Mahu. May 2, 1844 (Koloa and Mahu built a house together and later fought over who owned what. "The thatch, post, and rafters are not his. He owns only one piece of wood and that is the wooden post inside the house standing"); Waianuhe and Ahia, April 26, 1844 ("Waianuhea charges Ahia for keeping the chest. The reason the chest was given to me is this. Niniau surveyed the land"). 
Party A: B has my horse and will not give it to me.

Party B: It is not his horse; it is my horse, A gave it to me.

Party A: I did not give it to him; I let him use it because he was my friend.

This paraphrased version of a story that is repeated in the Minute Books indicates the confusion that the concept of property engendered with Native Hawaiians.

In pre-contact Hawaii, ownership of important goods, land, and resources was communal and was understood in terms of use rights rather than unitary absolute dominion. An individual or group may have had the right to gather thatch, for example, only from a particular section of land, and only during a particular time. Property was fragmented among various uses, various times, and various people. Families and groups of individuals could share components of property, and all were subject to the claims of others, such as the chiefs, that would take precedence. This sophisticated conception of ownership conflicted with the rather unsophisticated, unitary and physicalist conception of ownership ${ }^{65}$ introduced by nineteenth-century Westerners.

The Hawaiian conception of ownership was further complicated by the Hawaiian practice of giving away goods in exchange as part of the bonds of reciprocity and community. In the Hawaiian universe, the purpose of material wealth was to give it away and to thereby achieve a sense of self-worth and status, and to bind others to aid one in the future. ${ }^{66}$ In the Western universe, the purpose of material wealth was to hoard as much as possible so as to obtain more, to impress others, and to accumulate an abundance. The Hawaiians in Honolulu were becoming more and more attuned to the Western understanding of the purpose of property. This transition is also indicated in the many theft and contract cases that involve the pattern described above.

65. For a general discussion of the Intellectual history of the western concept of property, see Grey, The Disintegration of Property, 22 Nomos: Property 69 (1980); Vandevelde, The New Property of the Nineteenth Century: The Development of the Modern Concept of Property, 29 Buffalo L. Rev. 325 (1980); M. Horwitz, The Transformation of American Law (1977); Mensch, The Colonial Origins of Liberal Property Rights, 31 Buffalo L. Rev. 635 (1982).

66. See J. Linnekin, supra note 7. As noted supra note 4, the "status and exchange" anthropological model is problematic to some scholars because it implies a "what's in it for me" basis for the Hawaiian culture, rather than a joyful spirit of giving for its own sake. The remarkable generosity of the Hawaiians, noted again and again by early voyagers, and the persistence today of native Hawaiian generosity seems to encompass something more than the desire for status. 
In the case of Kapule and Naihe, ${ }^{67}$ for example, Naihe reports how the trouble began:

The reason for this is my wife rode to Moanalua and the horse fell down. There is a piece of property Kapule and I enjoy. He was very hospitable and gave medical attention. Kapule gave my wife and me things to make our difficulty there more bearable. Afterwards we gave Kapule money and some clothes. Kapule even gave Keaka, my wife, a horse. Then Keaka said to me "I am embarrassed by Kapule, your punalua [ 2 men sharing the same woman], because he gave me a horse. I am thinking of giving our canoe to your punalua." I said no. My wife returned to Ewa. After that, Keaka spoke again to me and asked to give the canoe. I agreed to give the canoe because he gave that very valuable horse. That horse which was given to my wife, Kapule and another gave to Kaanaana, their daughter in Kahuku.

The exchange of property Naihe described is not Western-style, titfor-tat barter. Rather, it is consistent with Hawaiian use of exchange to enhance mutual obligation and to achieve self-worth. ${ }^{68}$ As relations between the parties deteriorated, Naihe reported an entangled dispute that takes on a more Western conception of property:

Kapule did not agree to this saying "these gourds were sold to Naihe. I sold them for \$17.00." Then Kapule called for the money. [Naihe said] "I don't have it." That is what I said. Kapule said "I want to sail on our canoe." [I] gave it as [I] was done [with it]. Later Kapule came on that canoe. When I heard, I told my punalua to keep the canoe which he did. We three fought and I got the canoe. This is why I am keeping [it] because Kapule refused to give us [Naihe and Keaka] the horse.

The dispute then became a legal one, with each party claiming an enforceable right to the exchanged properties. The judges resolved the dispute by awarding Kapule the horse and Naihe the canoe. The Western conception of property - absolute dominion, individual ownership, legally enforceable title-prevailed and, more importantly, was promoted by the Native Hawaiians in their act of bringing this dispute to court.

67. Kapule and Naihe was the first case decided in 1844.

68. Present-day Hawaiians to whom the author has read the Kapule and Naihe excerpt consistently react with recognition of the Hawaiianess of Naihe's dilemma. 


\section{E. The Lay of the Land: Fencing-in}

Related to disputes over personal property are the many disputes over uses of land, ${ }^{69}$ fencing-in and fencing-out, ${ }^{70}$ and boundaries ${ }^{71}$ Loose animals - pigs, horses, and cattle-caused much damage to taro patches and gardens. This damage resulted in two types of cases: Landowners claiming damages for destruction of crops, ${ }^{72}$ and animal owners claiming damages for injury to or conversion of animals by angry (or covetous, or both) gardeners. ${ }^{73}$ The formal rule was one of fencing-in, that is, the owner who failed to fence in the loose animal was generally held liable for the destruction to crops. ${ }^{74}$ Gardeners who secreted or consumed roving animals were sometimes ordered to make restitution..$^{75}$

Lilikalani and Lahilahi $^{76}$ is a typical fencing case with a compromise verdict. Lilikalani tied up and held Lahilahi's horse after the horse damaged a vegetable garden. The judges did not fine Lilikalani for tying up the horse, nor Lahilahi for owning a roving animal, accepting Lahilahi's defense that he was not aware of the horse's activity. This type of no-winners result occurred in other fencing cases, and may reflect judicial reluctance to accept the full implications of the statutorily declared fencing-in rule. ${ }^{77}$ In the majority of cases, however, fines or restitution were imposed upon owners of roving animals. ${ }^{78}$

69. See, e.g., Kahui and Laea, Nov. 25, 1845 (boundary dispute).

70. Halai and Co., Nahinu and Kahula. January 4, 1844, are typical fencing dispute cases.

71. Kanaina and Koa, July 12,1844, is a typical boundary dispute, in which "Old-timers" testified over locations of stone and ditch property lines.

72. See, e.g., Hinaiuka and Kekeipi, June 5, 1844 ("I charge Kekeipi's horse of eating my dried pandanus leaves").

73. See, e.g., Keoni and Kaelepulu, Dec. 30, 1845 (no fine for holding a pig "because I was repeatedly annoyed by the pig eating in the garden"); Wahineomao and Kua. Oct. 13, 1845 (hapalua [ $1 / 2$ dollar] fine for eating a pig that ate 17 taro).

74. The Laws of 1842, XIX. Laws Respecting Lost and Found Goods, XIII. Running of Horses (including wild cattle).

75. Owners of animals, as well as the judges in trial, often asked of cultivators "what is the fine?" That is, "what restitution is appropriate for destruction of your crops?" See, e.g., Halai \& Co.. Nahinu and Kahula, January 4, 1844; Lilikalani and Lahilahi, January 6, 1844.

76. January 6, 1844.

77. In Hinaiuka and Kekeipi, supra note 72, the judges refused to impose a fine for the horse's transgression, perhaps because Hinaiuka had already sought self-help-he "beat up" the horse.

78. See, e.g., Waiakea and Keaka, July 1, 1844 (37 cents fine for a horse eating melons); Kaaukai and Kamaka, July 1, 1844 (6 cents for horse eating 2 ears of corn); Mahailani and Kanehailua, July I, 1844 (50 cents for pig eating 73 taro); Keawe and Mahina, July 7, 1845 (hapaha [ $1 / 4$ dollar] fine for horse eating plants); Kaiwi and Piikoi, Oct. 6, $1845(\$ 4.00$ fine for cow eating vegetables).

But see Kekai and Piena, Dec. 29, 1845 (no fine for pig eating vegetables where the vegetable garden was "not locked up and that is why the pig got in"). 
The fencing-in rule is an indication of the emerging urban character of Honolulu, and the emerging importance of the concept of absolute dominion. At other times in American history, fencing-out indicated communities with an excess of land and paucity of animals. ${ }^{79}$ As individual private ownership and yeoman homesteads become the order of the day, a fencingin rule typically gains hegemony. Government advisors were counseling the monarchy toward the yeoman farmer vision and would eventually succeed in institutionalizing that vision in Hawaii. ${ }^{80}$

Concern over furious riding and racing evidenced by the prosecution of those offenses also indicates the need for traffic order and quiet enjoyment of private property in the increasingly crowded town of Honolulu. ${ }^{81}$ Hawaiian willingness to bring fencing and furious riding cases to court evinces an emerging belief that the courts would support the claims of property owners to quiet enjoyment of their land.

\section{ANALYSIS: The Rise of Legal Consciousness in Hawaii}

The Honolulu Minute Books, valuable as a descriptive source, paint a picture of a Hawaii in transition, of cultural persistence and Western incursion, of changing conceptions of crime and property, and of a rapidly developing urban center.

Beyond the descriptive value, it is more difficult to draw explanatory conclusions. One may speculate upon reasons for the active use of the courts. The courts, it seems, offered something appealing to Hawaiians. Perhaps it was the small-town recreational value of a public forum to resolve disputes. Perhaps it was the need to achieve official redress and atonement for perceived violations in a time when the old religion and old hierarchy were fading away in fits and starts.

The more significant question is the extent to which the active use of a Western legal system added to the loss of Hawaiian culture and independence. While some members of the monarchy felt that a haole legal system would help ward off the expansionist threats of other nations, the rush to adopt Western institutions, in hindsight, seems to have created a welcoming environment for the non-Hawaiian investors, wealth-seekers, and expan-

79. Early colonial America and the early Western frontier are two examples. For a discussion of the fencing conflicts between Indians and colonial governments in New England, see J. Springer American Indians and the Law of Real Property in Colonial New England $30 \mathrm{Am} \mathrm{J}$. Legal Hist. 25, 50-51 (1986).

80. See generally Lam, The Imposition of Anglo American Laws of Land Tenure on Hawaiians, 22 J. Legal Pluralism 103 (1985); Chinen, The Great Mahele: Hawaii' S Land Law of 1848 (1957).

81. See, e.g., Re Kahilahila, January 3, 1844 in which Kahilahila denies furious riding and is acquitted. Most furious riding defendants were acquitted. See also Kauahi and $i$, Dec. 25 , 1845 (furious riding charges dismissed); Piikoi and Kalua, Oct. 4, 1845 (same). 
sionists who eventually had their day in Hawaii. Of the many economic, political, and social effects that were destructive of Hawaiian culture, the law, with its official institutional presence, was surely one of those forces. It was not possible for Hawaiians to use Western law instrumentally while resisting Western law ideologically.

The Minute Books suggest three ways in which law altered Hawaiian consciousness.

First, a system of law is a state-sponsored formal mechanism for dispute resolution. The availability of this mechanism competed with and ultimately displaced existing customary mechanisms. In many of the cases in the Minute Books there is evidence that the parties attempted to resolve the dispute informally before resort to the courts. In one case a party described a prolonged exchange of complaints and then reported his decision to "leave it alone until the trial." 82 The painstaking traditional Hawaiian method of ho' oponopono, ${ }^{83}$ - the lengthy talking-out of disputes in a ceremony of prayer, vocalized frustration, emotion, and ultimate forgiveness-depended for success upon the need of all parties for peace and the lack of available alternatives. Disputants in Honolulu in 1844 now had a new and more efficient method of dispute resolution. Anyone losing patience with endless neighbor-to-neighbor haggling could go to court and get a judgment.

The court's use of compromise judgments, frequent dismissals, and small, restitution-type fines enhanced its legitimacy. In general, the decisions provided rough justice and no one was treated so harshly as to cause rejection of the system.

The adoption of the new judicial system carried with it implicit assumptions about power. The power to decide disputes was the power to distribute land, goods, and wealth with finality. The idea of locating this power outside of the hierarchy of the kinship community, in neutral arbitrators who had no special knowledge of the facts, was a new one, and a significant one in the years of change that lay ahead. ${ }^{84}$ Also

82. In Halai and Co., Nahinu and Kahula, January 4, 1844, a party in a dispute over a roving pig that rooted in a taro patch reported attempting settlement with his neighbor. After several frustrating exchanges, the neighbor finally attempted to return the pig. Halai reported replying "my thoughts about the pig are over. Leave it alone until the trial."

83. See notes 15-17, supra.

84. While the Hawaiians were growing accustomed to using the courts, the Kingdom, at the urging of haole advisors, was establishing a new Land Commission, a quasi-judicial body that would play a crucial role in the transformation from communal to individual title in Hawaii. See J. Chinen, The Great Mahele, Hawaii' s Land Division of 1848 (1958) (describing the division of land and the system of land commission awards that led to universalized private land ownership in Hawaii). 
new was the idea that the court could decide cases with finality even where one of the parties was unhappy with the result. The acceptance of these notions of dispute resolution had obvious significance in an island nation, where control over land would be a prime source of political conflict in years to come.

Second, in addition to altering customary concepts of dispute resolution, the new legal system also promoted an ideology of property that competed with native ideology. The concept of individual, absolute dominion over private property, represented in statutes governing theft, fencingin, contracts, and of course, land ownership, were central to the new law and to most of the cases that came before the courts. It was not possible to embrace Western law and not accept, in part, the concept of private property.

Native Hawaiians in the 1840 s generally opposed the selling of land to foreigners. Thousands signed petitions against such sales, urging the government to keep the land for Hawaiians. ${ }^{85}$ The Hawaiians themselves, however, were coming to accept the legitimacy of absolute, individual dominion over property. Belief in private property was an implicit part of any effort to seek court adjudication of property disputes. There were no property decisions rendered with a judgment advising the parties to "go home and share this property for the good of both of you." The Hawaiian result of communal ownership and generous exchange simply could not be obtained in a Western-style court, even with Hawaiian judges inclined to render compromise judgments.

The judges, who perceived that their power included the waiver of a fine or the forgiving of the wanderings of an incorrigible cow, somehow understood that their discretion did not extend to the disintegration of property. This indicates that there are, in Western legal consciousness, concepts with pull-strong magnets that are so central to the system that they affect even the adjudications at its lay peripheries. The commoner who demanded the return of his canoe, and the lay judge who awarded it, both comprehended very early in the history of the introduction of Western law to Hawaii that in matters of ownership of property there were winners and losers, owners and non-owners, with no room for intermediary results. This distinctively non-Hawaiian concept was adopted with dramatic alacrity and consistency in the District Courts, even where other legal concepts were regularly blurred, ignored, or transcended. The Minute Books suggest that the concept of absolute, individual ownership of property was one the Hawaiians could not resist if they were going to use the system of Western law. It was sine qua non of the system, a concept of irresistible force. 
Indeed, the emergence of the concept of private property in lay discourse so early in the development of the system of statutes and courts suggests that the concept was transferred in part from lay Westerner to lay Hawaiian before the full-fledged, formal reception of Western law. ${ }^{86}$ Just as microorganisms can transfer chromosomal messages, short-cutting the process of life, death, and accretionary change, so can non-elite human beings in cross-cultural contact transfer legal consciousness. Ready access to the new court system then had a reinforcing and multiplying effect, adding state authority to the newly-emerging ideal. The courts were generally fair, informal, and open to all comers, hastening this effect.

Court-enforced individual ownership of chattels was one easy step away from individual Hawaiian ownership of land, which was one easy step away from sales to foreigners. The Hawaiians who opposed land sales to foreigners may have hurt their own cause by going to the new courts to settle disputes over the gourd money. Active use of the courts to resolve property disputes paved the conceptual way for the formal institution of universalized private title in land in $1848 .^{87} \mathrm{By} 1850$ foreigners could buy land in Hawaii, ${ }^{88}$ and by 1865 they controlled most of it. ${ }^{89}$ This is not to suggest that the changes in land distribution were solely the result of the acceptance of a Western legal system. Rather, the suggestion here is that the Hawaiians' active use of the new law altered their consciousness in a significant way and made it more difficult for them to challenge the legitimacy of the new land tenure rules.

Finally, the system of legal rules and judicial enforcement provided a welcome mat for the newcomers intent on economic development of Hawaii. While capitalists will venture wherever there is money to be made, the presence of a familiar legal system reduces business risks, or perhaps more significantly, the perception of risk, and thus encourages investment. Law welcomed business, and the new business interests brought more people, things, and ideas that were non-Hawaiian. Eventually, those inter-

86. Indeed, conflict over the concept of property arose at first contact with the haole. Captain Cook reported that Hawaiians "thought they had a right to everything they could lay their hands upon.*** [but] they soon laid aside a conduct which, we convinced them, they could not persevere with impunity." J. Cook and J. King, A Voyage to the Pacific Ocean in His Majesty's Ships Resolution and Discovery (1784) as quoted in M. Sahlins, supra note 6. Cook's firm commitment to private ownership was in part the cause of his death. He was killed in an attempt to kidnap a chief in an effort to recover a boat taken by the Hawaiians. See M. Sahlins, supra note 6, at 104-134 for one version of Cook's demise.

87. See J. Chinen, supra note 84.

88. Act of July 10, 1850, Laws of Hawaii 1850 at 146; Revised Laws of Hawaii 1925, vol. II at 2233-34.

89. MacGregor-Alegado, supra note 37, at 44, 99. 
ests were responsible in large part for the overthrow of the Hawaiian government and annexation to the United States. ${ }^{90}$

Does law destroy culture? No, it does not. Law and legal consciousness can, however, work in concert with other forces to alter culture.

This claim, if it is correct, carries present-day significance. Hawaiians continue to argue whether the use of the courts to seek redress for past injustice is part of a co-option process, and a recognition of the essential legitimacy of a colonial legal system. ${ }^{91}$

In newly sovereign Pacific Island nations indigenous leaders are adopting Western codes ${ }^{92}$ and wondering what effect these imported laws will have on existing cultural norms. A more specific question is whether such nations can adopt Western laws of crime, contracts, civil liability, and procedure while maintaining traditional communal land and property concepts, ${ }^{93}$ as they are attempting to do. The Hawaiian experience shows that the breakdown of traditional conceptions of property begins long before title is formally transformed.

Perhaps there is value in Western law that emerging nations can use. And perhaps, looking at the history of Hawaii, they can take care to protect what is valuable in their own culture as they use the tool of law.

\section{CONCLUSION}

The nineteenth-century emergence of Western legal consciousness in Hawaii is evident in the day-to-day activity of Hawaii's commoner courts. The ordinary Hawaiian, sometimes viewed as the passive victim of outside forces, ${ }^{94}$ was in fact an active and creative participant in the changing

90. For a history of annexation, see generally, T. Osborne, Empire Can Wait (1981).

91. The Hawaiian lawyer-activist Hayden Burgess takes the position that Hawaiians need not recognize the authority of federal courts in Hawaii.

92. The Federated States of Micronesia has adopted, for example, The United States Federal Rules of Evidence and The Federal Rules of Civil Procedure. This adoption of complex statutes by a new country with lay judges and few lawyers shows the strength of the push to legalism.

93. The Republic of Palau, a country that has formally received a western legal system, is attempting to maintain traditional Palauan land ownership in the face of economic pressure to build hotels, as well as political pressure to accommodate the U.S. military.

94. The new Pacific historiography attempts to transcend the conventional view of Pacific islanders as overwhelmed and silenced by the coming of Europeans. See K.R. Howe, supra note 25 , at 347-348. The instant article, in attempting to understand the role of Hawaiian commoners in the adoption of legal consciousness in Hawaii, is not intended to conflict with the view that Native Hawaiians were indeed victimized by colonialism. See, e.g., H. Trask, Hawaiians, American Colonization, and the Quest for Independence, 31 Social Process in Hawaii 101 (1984-85). 
culture of the islands. Hawaiians used the courts and the law, adjusting quickly to a radically different social order. The ultimate effect of this new order, modern-day Hawaiian activists assert, was harmful to Hawaiians. The adaptability of the Hawaiians, the swiftness of change, and the Hawaiian role in it, however, suggests an ultimately hopeful historical possibility: Hawaiians in their words, their deeds, and their beliefs, can participate in the creation of the future Hawaii, and they can imbue that Hawaii with the richness of their Hawaiian past. 